\title{
KREATIVITAS GURU PENDIDIKAN AGAMA ISLAM DALAM MENGEMBANGKAN MEDIA PEMBELAJARAN BERBASIS ICT
}

\author{
Ahmad Ghifari Tetambe \\ Intstitut Agama Islam Negeri (IAIN) Kendari \\ ahmadghifari@iainkendari.ac.id
}

Dirman

Institut Agama Islam Negeri (IAIN) Kendari dirman@iainkendari.ac.id

\begin{abstract}
Abstrak
Penelitian ini bertujuan untuk mendeskripsikan dan menganalisis 1) Penggunaan media pembelajaran berbasis ICT dalam pembelajaran PAI di MTs Negeri 1 Konawe, 2) Kreativitas guru Pendidikan Agama Islam dalam mengembangkan media pembelajaran berbasis ICT dalam proses pembelajaran PAI di MTs Negeri 1 Konawe. Penelitian ini dilakukan dengan menggunakan pendekatan kualitatif, yang menjelaskan, mendeskripsikan, menyelidiki dan memahami secara menyeluruh terhadap peristiwa dan gejala-gejala yang diteliti dengan situasi yang dialami. Pendekatan kualitatif ini menurut peneliti sangat relevan dalam penelitian ini karena bertujuan untuk mendeskripsikan Penggunaan media pembelajaran berbasis ICT dalam pembelajaran PAI di MTs Negeri 1 Konawe dan Kreativitas guru Pendidikan Agama Islam dalam mengembangan media pembelajaran berbasis ICT di MTsN 1 Konawe. Berdasarkan wawancara terhadap 15 orang informan yang terdiri atas Kepala Madrasah, Guru PAI dan siswa maka peneliti mendapatkan hasil yang menunjukkan bahwa 1) Penggunaan media pembelajaran berbasis ICT meliputi penggunaan what's app, blog, dan e-mail. Dalam proses penggunaanya ke tiga media tersebut dikolaborasikan dalam proses pembelajaran, 2) kreativitas guru Pendidikan Agama Islam di MTsN 1 Konawe dapat dilihat dari hasrat untuk mengubah hal-hal di sekelilingnya menjadi lebih baik, memiliki kepekaan untuk bersikap terbuka serta tanggap terhadap segala sesuatu, siap mencoba dan melaksanakan, bersedia mencurahkan waktu dan tenaga untuk mencari serta mengembangkan, dan memiliki optimisme.
\end{abstract}

Kata Kunci: Kreativitas Guru, Media Pembelajaran, ICT.

\begin{abstract}
The purpose of this study is to describe 1) The use of learning media based on ICT in Islamic education learning in MTs Negeri 1 Konawe, 2) The creativity of Islamic education teacher in developing learning media based on ICT in the process of Islamic education learning in MTs Negeri 1 Konawe. This research was conducted using a qualitative approach, which was tried to explain, describe, investigate and
\end{abstract}


comprehensively comprehend the events and symptoms studied in natural / natural situations.This qualitative approach, according to the researcher, is very relevant to this research because it aims to describe the use of learning media based on ICT in Islamic education learning in MTsN 1 and the Creativity of Islamic Education teachers in developing learning media based on ICT in MTsN 1 Konawe. Based on interviews of 15 informants consisting of madrasah heads, PAI teachers, and students, the researchers obtained the results of this study indicate that: 1) the use of learning media based on ICT includes the use of what's app, blog, and e-mail. In the process of using those three medias were collaborated in the learning process, 2) the creativity of the Qur'an Hadith teacher in MTsN 1 Konawe can be seen from the desire to change things around himbe better, have the sensitivity to behave open and responsive to everything, ready to try and implement, willing to devote time and energy to find and develop, and have optimism.

Keywords: Creativity, Learning Media, ICT.

\section{Pendahuluan}

Sistem pembelajaran secara keseluruhan tidak terlepas dari peran media menunjang keberhasilan proses pembelajaran. Dalam proses pembelajaran sebaiknya pemanfaatan media mendapatkan perhatian oleh para guru dalam proses belajar mengajar. Akan tetapi, karena beberapa alasan hal ini masih sering terabaikan. Menurut Iwan falahudin (Falahudin, 2014) Pemanfaatan media seharusnya merupakan bagian yang harus mendapat perhatian pembelajar dalam setiap kegiatan pembelajaran. Namun kenyataanya bagian inilah yang masih sering terabaikan dengan berbagai alasan. Beberapa alasan yang muncul seperti: kurangnya waktu dalam membuat persiapan mengajar. Kesulitan mendapatkan media yang tepat, kurangnya biaya dan lain sebagainya. Problematika ini tidak akan terjadi jika setiap individu guru mempunyai pegetahuan dan keterampilan dalam bidang media pembelaran. Di era sekarang, sudah beragam, media-media yang dapat dipilih oleh setiap guru yang selalu dapat berkembang sesuai kondisi, waktu dan biaya sehingga akan tercapai tujuan pedidikan yang diinginkan. Apapun media yang digunakan maka kita harus paham dalam memakainya karena pemakain tersebut harus sesuai dengan kebutuhan, fakta dan lingkungan sekitar. Kegiatan belajar mengajar dengan menggunakan media pembelajaran akan dapat memberikan kesenangan dan membangkitkan minat siswa serta dapat membawa pengaruh-pengaruh positif terhadap siswa tanpa adanya suatu media pembelajaran modern maka hasil belajar perserta didik akan sulit untuk mendapatkan peningkatan. Dengan media pembelajaran yang dirangkai dengan bagus 
serta dilengkapi isi yang menarik akan menjadikan siswa memanfaatkan media pembelajaran sebagai alat bantu belajar.

Dalam rangka memajukan kualitas mutu pembelajaran maka perlu didasarkan pada pandangan yang lebih sistematis, yang juga harus didukung dengan usaha memanfaatkan dan meningkatkan kualitas sumber dan media belajar. Pada era modern ini begitu pesat memanfaatkan ICT (Information, Communication and Tecnology) sebagai sumber dan media pembelajaran di lembaga pendidikan bisa menjadi upaya untuk mengahasilkan kualitas pembelajaran dan mutu pendidikan. Sehingga perlu adanya inovasi baru dalam proses pembelajaran yang menggunakan alat beruba teknologi sebagai sumber dan media pembelajaran berbasis ICT . Media Pembelajaran berbasis ICT adalah media pembelajaran yang memadukan komponen-komponen yang terdapat pada $I C T$.

Munculnya ICT di era modern ini telah memudahkan hubungan komunikasi oleh guru dan siswa dan sumber-sumber belajarpun dapat diakses dimanapun. Beberapa kelebihan yang dimiliki ICT adalah dalam proses penyajian dan penyampaian materi yang sifatnya lebih menarik dan menyenangkan dalam proses pembelajaran. Selain itu, ada beberapa tantangan untuk para guru dan dosen yang dituntut untuk menguasai pemanfaatan ICT sehingga mencapai tujuan pembelajaran yang efektif dan efisien.

Selain itu, sebagai profesional guru harus memiliki kemampuan membelajarkan siswa, kreatif dan memiliki kemampuan dalam mengatur informasi serta lingkungan (yang meliputi tempat belajar, metode, media, sistem penilaian, serta sarana dan prasarana) dalam kegiatan belajar siswa sehingga menjadi lebih efektif dan efisien. Olehnya itu, pembelajaran ICT telah memperkaya beberapa sumber dan media seperti buku, transparasi OHP, Slide power point, foto, dan lain sebagainya, sehingga guru yang cakap harus mampu mengembangkan serta memanfaatkan kecanggihan yang dimiliki sistem ICT tersebut.

\section{Metode Penelitian}

Artikel ini menjelaskan dan menganalisis bagaimana kreativitas Guru PAI dalam mengembangkan media pembelajaran berbasis ICT. Artikel ini menggunakan pendekatan kualitatif deskriptif, yang mencoba memahami secara menyeluruh pada peristiwa dan gejala-gejala yang diteliti di lapangan. Pendekatan kualitatif ini menurut peneliti sangat relevan dalam penelitian ini karena bertujuan untuk mendeskripsikan 
Penggunaan media pembelajaran berbasis ICT dalam pembelajaran PAI di MTs Negeri 1 Konawe dan Kreativitas guru Pendidikan Agama Islam dalam mengembangan media pembelajaran berbasis ICT di MTsN 1 Konawe.

\section{Konsep Kreativitas Guru Pendidikan Agama Islam}

Kreativitas guru Pendidikan Agama Islam merupakan suatu sebutan terhadap kualitas sikap para guru Pendidikan Agama Islam terhadap profesinya serta derajat pengetahuan dan kemampuan yang mereka miliki agar dapat melakukan tugas-tugasnya. Dengan demikian, istilah guru Pendidikan Agama Islam yang kreatif lebih menggambarkan suatu keadaan derajat keprofesian setiap guru Pendidikan Agama Islam untuk bangkit menggapai sikap, pengetahuan, dankeahlian yang diperlukan untuk melaksanakan tugasnya dalam pembelajaran bidang studi Pendidikan Agama Islam. Dalam hal ini, guru Pendidikan Agama Islam diharapkan memiliki Kreativitas sehingga guru sebagai tenaga pendidik mampu melaksanakan tugasnya secara efektif. Dalam megelola pendidikan maka Islam sangat memperhatikan peran seorang guru. Mereka memiliki peranan yang sesuai dalam menciptakan generasi Qur'ani, berkarakter dan berkualitas. Seorang guru yang kreatif begitu menentukan generasi yang tumbuh dengan kekuatan iman da taqwa, menguasai teknologi serta mampu menuju meningkatkan nilai Islam yang kaffah dan mengamalkan Islam sebagai rahmatan lil' alamin.

Kreativitas guru Pendidikan Agama Islam tidak terbentuk secara langsung, akan tetapi ada terdapat beberapa faktor yang menjadi pendukung kreativitas seorang guru Pendidikan Agama Islam dalam mengembangkan materi pembelajaran, yaitu: 1) Pengalaman mengajar, 2) Motivasi guru, 3) Gaya kepemimpinan kepala sekolah, 4) Guru memiliki bakat, 5) Ketersediaan media (Mujakir, 2017).

Dari beberapa penjelasan tersebut dapat diketahui bahwa guru PAI yang kreatif adalah guru yangmemiliki kecerdasan (intelegensi), sehingga mampu berpikir secara kritis untuk mendapatkan sesuatu yang berbeda, diperoleh melalui keterampilan ataupun pengalaman, baik pengalaman sendiri ataupun orang lain. Pengalaman dimasa kecil mempengaruhi kreativitas seseorang, baik dari segi pendidikan ataupun keluarga.

Keberadaan guru Pendidikan Agama Islam sebagai pendidik utama dalam menjalankan pendidikan agama Islam sehingga bisa berperan menjadi perancang, 
pelaksana, pemimpin, komunikator dan evaluator terhadap proses pendidikan Agama Islam dalam kerangka mencapai tujuan terbentuknya kepribadian anak didik yang luhur. Secara filosofis, individu merupakan manusia berasal dari Tuhan dan kembali Tuhan yang diberi tanggung jawab sebagai pemimpin dan abdun (hamba), dalam kerangka misi menemukan dan mengamalkan sunnatullah sebagai bekal keselamatan bagi manusia.

Peran para pendidik dalam mendidik anak tentu saja harus diarahkan untuk mengembangkan potensi/talenta anak secara maksimal dan menyiapkan lingkungan yang kondusif bagi pembelajaran sehingga tercapai kedewasaanyang maksimal (intelektualitas, moralitas, estetik, spiritualitas) sebagaimana pribadi muslim sejati/insan sholeh. Tegasnya, pribadi yang diinginkan sistem pendidikan Islam adalah yang memiliki kecerdasan intelek, emosi dan spiritual secara terpadu.

Guru yang kreatif disenangi oleh peserta didik, baik saat proses pembelajaran yang berlangsung di dalam kelas maupun diluar kelas. Oleh karena itu, selain kreativitas dalam mengajar, guru sebaiknya memiliki kompetensi. Kompetensi yang harus dipenuhi sebagaimana dalam Peraturan Pemerintah (PP) Nomor 19 tahun 2005 tentang standar nasional Pendidikan yang dikutip oleh Hamid Darmadi, menyebutkan ada 4 kompetensi guru antara lain: kompetensi pedagogik, kompetensi kepribadian, kompetensi profesional, dan kompetensi sosial (Darmadi, 2000).

Berdasarkan uraian diatas, dapat di ketahui bahwa guru PAI tidak hanya memiliki kompetensi dalam mengajar tetapi nilai-nilai yang diajarkan dapat diaplikasikan pada keseharian baik itu disekolah maupun dirumah. Sebelum proses pembelajaran berlangsung, guru harus mempersiapkan materi dan perencanaan pembelajaran bertujuan agar hasil yang diinginkan dapat tercapai. Ada banyak cara yang dapat dilakukan guru diantaranya dengan pergaulan sehari-hari, keteladanan, ajakan dan mengamalkan nilai-nilai yang Islami dalam kehidupan sehari-hari. Semua ini tidak dapat dilakukan jika hanya guru agama yang menerapkannya, tetapi semua guru yang berada di lingkungan sekolah sehingga tercipta lingkungan yang Islami.

\section{Konsep Pengembangan Media Pembelajaran Berbasis ICT}

Pengembangan (Development) merupakan perbuatan mengembangkan, pembangunan secara baik yang mengarah ketujuan yang dikehendaki (Departemen, 
2003). Pengembangan memiliki keterkaitan dengan inovasi, namun kedua kata ini memiliki makna yang berbeda. Inovasi adalah bagian dari pengembangan, dan dapat pula diartikan sebagai sesuatu yang baru dalam situasi sosial tertentu yang digunakan untuk menjawab atau memecahkan suatu permasalahan (Sanjaya, 2008).

Pada dunia kepustakaan riset inovasi kadang dicampur aduk dengan istilah kreatif. Benadicta dalam bukunya kewirausahaan menurut pandangan psikologi kepribadikan. Dalam membedakan definisi tersebut, maka Wehner, Csikzzenrmihalyi dan Magyrei Back meneliti 100 disertasi mereka menemukan bahwa kreatitas lebih familiar dikenal dengan inovasi cenderung pada tingkat organisasi. Jika dalam bidang psikologi kreatifitas lingkupnya cenderung dilihat pada tingkat individu. sedangkan inovasi itu merupakan kreatifitas tingkat organisasi (Riyanti, 2003).

Dari uraian di atas maka terdapat kesamaan dan perbedaanya pada tempat penerapannya, lebih menekankan pada gagasan dan inovasi terkait penerapan gagasan tersebut. Dari definisi inovasi tersebut maka diketahui tidak terjadi perbedaan yang mendasar. Jika muncul ketidaksamaan itu disebabkan karena susunan kalimat dan maksudnya. Secara umum definisi tersebut menyebutkan bahwa inovasi adalah suatu ide, hal praktis yang dapat diamati dan dirasakan bagi individu atau kelompok masyarakat. Hal itu dapat berupa invensi maupun discovery, yang berfungsi untuk mencapai tujuan dalam memecahkan suatu masalah.

Media pembelajaran adalah sarana untuk meningkatkan kegiatan proses belajar mengajar. Mengingat banyaknya bentuk-bentuk media tersebut, maka pendidik harus dapat memilihnya dengan cermat, sehingga dapat digunakan dengan tepat. Dalam kegiatan belajar mengajar, sering pula pemakaian kata media pembelajaran digantikan dengan istilah-istilah: bahan pembelajaran, komunikasi pandang-dengar, alat peraga pandang, alat peraga dan media penjelas (Asnawir \& Usman, 2002).

Berdasarkan Pengertian diatas dapat diketahui bahwa media pembelajaran merupakan wadah dari pesan yang oleh sumber atau penyalurnya ingin diteruskan kepada sasaran yaitu penerima pesan tersebut. Bahwa materi yang ingin disampaikan adalah pesan pembelajarannya serta tujuan yang ingin dicapai adalah terjadinya proses belajar mengajar. Apabila dalam satu dan hal lain media tidak dapat menjalankan sebagaimana fungsinya sebagai penyalur pesan yang diharapkan, maka media tersebut tidak efektif dalam arti tidak mampu mengkomunikasikan isi pesan yang diinginkan dan 
disampaikan oleh sumber kepada sasaran yang ingin dicapai. Media pembelajaran adalah alat yang dapat membantu proses pembelajaran dan berfungsi sebagai memperjelas makna pesan yang disampaikan, sehingga dapat mencapai tujuan pembelajaran dengan lebih baik dan sempurna.

Berdasarkan penjelasan diatas mengenai definisi dari pengembangan dan media pembelajaran, dapat diketahui bahwa pengembangan media pembelajaran adalah proses atau langkah yang dilakukan untuk membuat atau menyempurnakan sebuah media pembelajaran agar sesuai dengan design pembelajaran yang dibuat dengan tujuan untuk meningkatkan kegiatan proses belajar mengajar yang lebih efektif, kreatif dan inovatif. Dengan perkembangan teknologi yang semakin maju guru sebagai pendidik dituntut agar dapat mengembangkan sebuah media pembelajaran sehingga proses pembelajaran menjadi semakin menarik dan semakin meningkatkan kualitas belajar peserta didik.

\section{Hasil Penelitian dan Pembahasan}

Media merupakan salah satu sarana pendidikan untuk meningkatkan kualitas pembelajaran. Salah satu manfaat media ini adalah sebagai alat bantu yang dapat menunjang keberhasilan mengajar. Media juga berfungsi untuk meningkatkan pemahaman siswa terhadap materi pelajaran. Melihat betapa pentingnya media dalam mengajar, maka guru dituntut harus mampu kreatif dan inovatif dalam memilih dan menggunakan media tersebut pada proses belajar mengajar. Penggunaan media yang sesuai akan meningkatkan kualitas khususnya proses pembelajaran.

Kreativitas adalah keinginan dalam membuat kombinasi-kombinasi baru, atau melihat kombinasi antar unsur, data atau hasil yang sudah ada sebelumnya. Dengan demikian, dapat dijelaskan bahwa kreativitas merupakan usaha-usaha untuk menyatukan berbagai hal, dari objek-objek yang ada sebelumnya hingga menjadi sesuatuyang baru. Kreativitas guru dalam penggunaan media pembelajaran dapat membentuk media pembelajaran yang inovatif.

Berdasarkan hasil penelitian diketahui bahwa dalam proses pembelajaran di kelas, guru Pendidikan Agama Islam di MTsN 1 Konawe mengembangkan media pembelajaran berbasis ICT dengan berorientasi pada penggunaan What's App, Blog, dan E-mail. Hal ini dapat diamati melalui proses pembelajaran yang sedang dilaksanakan di kelas. Dalam implementasinya, guru Pendidikan Agama Islam 
mengkombinasikan ketiga media tersebut dalam proses pembelajaran. Beberapa fakta yang penulis amati, ternyata guru Pendidikan Agama Islam menggunakan media pembelajaran yang sangat menarik yaitu dengan menggabungkan what's app, blog, dan e-maill dalam proses pembelajaran, sehingga peserta didik merasa senang dan tertarik belajar Pendidikan Agama Islam. Hal lain yang penulis amati langsung dalam proses penggunaan what's app, blog, e-mail pada saat mengajar, yaitu; guru memberikan siswa tugas untuk mencari ayat dan hadits tentang menjaga kelestarian lingkungan dan penerapannya dalam kehidupan sehari-hari, yang tugas tersebut kemudian dijadikan bahan diskusi di grup chat what's app saat pulang sekolah. Dari tugas tersebut, Berdasarkan proses pembelajaran yang penulis amati di atas, dapat ditarik kesimpulan bahwa proses pembelajaran menggunakan what's app, blog dan e-mail dapat memberikan inspirasi kepada peserta didik untuk mengarahkan perhatiannya terhadap materi yang diajarkan. Dengan demikian, guru Pendidikan Agama Islam mampu mengembangkan media pembelajaran untuk digunakan oleh peserta didiknya. Sehingga dalam proses penilaian atau evaluasi guru menilai rasa antusias dan partisipasi siswa dalam proses pembelajaran.

Hasil penelitian ini mengungkapkan tentang penggunaan media pembelajaran berbasis ICT dalam pembelajaran Pendidikan Agama Islam di MTsN 1 Konawe dan kreativitas guru Pendidikan Agama Islam dalam mengembangkan media pembelajaran berbasis ICT pada proses pembelajaran Pendidikan Agama Islam di MTs Negeri 1 Konawe.

\section{Penggunaan Media Pembelajaran Berbasis ICT dalam Pembelajaran Pendidikan Agama Islam di MTsN 1 Konawe}

Berdasarkan hasil penelitian ini diketahui penggunaan media pembelajaran berbasis ICT meliputi penggunaan aplikasi What's App, Blog, dan E-maill. Ketiga aplikasi tersebut merupakan bentuk pengembangan media pembelajaran berbasis ICT. Ketiga aplikasi tersebut merupakan bentuk pengembangan media pembelajaran berbasis ICT yang akan dijelaskan sebagai berikut:

\section{a. What's App}

Penggunaan what's app sebagai media pembelajaran yang digunakan oleh guru Pendidikan Agama Islam adalah salah satu bentuk pengembangan media pembelajaran berbasis ICT yang proses penggunaannya dengan membuat sebuah grup chat yang dari 
grup tersebut guru Pendidikan Agama Islam mengirimkan berbagai materi pelajaran Pendidikan Agama Islam. Al Saleem mengatakan bahwa dalam WhatsApp Messenger terdapat Whatsapp Group yang mampu menjadikan sebuah pembelajaran yang menyenangkan terkait berbagai topik diskusi yang diberikan oleh pengajar (Alsaleem, 2013).

Sejalan dengan pernyataan Al Saleem di atas, dalam grup what's app yang dibuat oleh guru Pendidikan Agama Islam dapat menjadi media diskusi materi pelajaran Pendidikan Agama Islam antara guru dengan siswa dan juga antara siswa dengan siswa lainnya, hal ini menunjukkan bahwa dalam penggunaan what's app sebagai media pembelajaran terdapat proses hubungan timbal balik antara guru dan siswa.

Proses pembelajaran dengan menggunakan aplikasi WhatsApp dikatakan sebuah pembelajaran yang menyenangkan sebab, aplikasi what's app merupakan media komunikasi yang familiar digunakan oleh semua kalangan tidak terkecuali siswa. Dengan mengintegrasikan materi pembelajaran pada aplikasi what's app memberikan kesempatan kepada siswa untuk belajar maupun diskusi dengan teman-temannya dimanapun dan kapanpun.

Bruce W Dearstyne (Dearstyne, 2011) dalam tulisannya yang berujudul "Smart phones: The new information revolution?"menuliskan "WhatsApp Messenger is a popular technology that has the potential to be used as a learning tool". WhatsApp Messenger merupakan teknologi popular yang sangat berpotensi untuk digunakan sebagai alat pembelajaran. Dikatakan sangat potensial sebab what's app dapat digunakan dan diakses kapan saja dan dimana saja oleh siswa menggunakan smartphone.

Dewasa kini, smartphone telah menjadi kebutuhan primer oleh semua kalangan tidak terkecuali bagi siswa. Fitur dan spesifikasi smartphone yang senantiasa selalu diinovasikan menjadikan smartphone bukan lagi hanya menjadi alat komunikasi melainkan menjadi alat multimedia yang dapat digunakan hampir dalam segala aspek kehidupan. Oleh karena itu smartphone telah menjadi alat multimedia yang dapat diaplikasikan sebagai media hiburan mulai dari mendengarkan musik, menonton, berfoto dan bermain game, maka tingkat ketergantungan siswa terhadap smartphone tersebut semakin tinggi. Muflih (Muflih et al., 2017) menjelaskan Remaja akan gelisah jika berpisah dengan smartpone, namun merasa biasa saja ketika ditinggal pergi orang 
tuanya. Jika hal ini dibiarkan terus-menerus, orang tua akan kehilangan anak anak mereka. Sementara remaja akan menjadi kecanduan dan lebihsayang pada smartphone. Penggunaan smartphone secara terus menerus akan mengarah kepada kecanduan. Kecanduan akan smartphone akan menyebabkan remaja melupakan tugas belajarnya, dan juga pemenuhan kebutuhan dasarnya seperti makan, minum, atau mandi. Melihat efek ketergantungan penggunaan smartphone pada siswa maka dalam proses pembelajaran guru PAI di MTsN 1 Konawe kemudian mengembangkan kreativitasnya untuk membentuk media dan suasana belajar yang dinamis sesuai dengan kondisi siswa sehingga proses pembelajaran dapat berjalan dengan efektif dan efisien.

\section{b. Blog}

Blog merupakan media pembelajaran yang berbasis ICT yang digunakan oleh Guru Pendidikan Agama Islam di MTsN 1 Konawe. Berdasarkan hasil penelitian, diketahui bahwa blog digunakan sebagai rangkuman materi Pendidikan Agama Islam yang akan didistribusikan kepada siswa melalui aplikasi grup chat what's app.

Blog adalah salah satu media pembelajaran berbasis ICT yang memudahkan siswa dalam proses pembelajaran. Berdasarkan hasil penelitian diketahui bahwa, penggunaan blog sebagai media pembelajaran berbasis ICT oleh Guru Pendidikan Agama Islam di MTsN 1 Konawe memiliki manfaat yang memberikan dampak positif kepada siswa. Salah satu dampak positif yang diberikan adalah hanya dengan bermodalkan smartphone dan koneksi internet siswa dapat mengakses materi pelajaran yang telah disediakan oleh Guru Pendidikan Agama Islam. Hal ini sebagaimana dikutip dari tulisan Nasrullah dan Ruly yang menyatakan bahwa salah satu kelebihan blog adalah memudahkan siswa untuk meng-update atau men-download materi-materi pembelajaran yang ada dalam blog pengajar yang selaras pada mata pelajaran yang butuhkan seseorang (Nasrullah, 2008). Dari penjelasan ini dapat disimpulkan bahwa blog merupakan alat/media pembelajaran yang dapat memberikan kemudahan bagi siswa dalam pelaksanaan proses pembelajaran dikarenakan blog merupakan salah satu media yang mudah di akses oleh siswa hanya dengan mengunjungi alamat url yang telah diberikan oleh guru Pendidikan Agama Islam. 


\section{c. E-Mail}

E-Mail adalah salah satu bentuk pembaruan media pembelajaran berbasis ICT yang diaplikasikan oleh Guru Pendidikan Agama Islam di MTsN 1 Konawe. Dari penelitian diketahui bahwa E-Mail digunakan oleh Guru Pendidikan Agama Islam sebagai media siswa mengumpulkan tugas siswa. E-Mail juga mempermudah siswa dalam menyetorkan tugas dan juga memudahkan guru dalam memberikan nilai dari tugas siswa. Anwar Mawansih (Mawarsih, 2014) dalam tulisannya mengemukakan bahwa: "Perkembangan pendidikan menjadikan layanan internet elctronis mail sangat bermanfaat dalam kehidupan. Beberapa manfaat yang dapat diketahui seperti dapat diguakan sebagai media penerangan yang akan membawa dampak positif bagi mahasiswa terkhsus tugas yang diberikan oleh para dosen".

Berdasarkan pernyataan di atas diketahui bahwa E-Mail memiliki manfaat dalam dunia pendidikan, E-Mail bukan hanya dipakai sebagai media berkirim pesan tapi dapat juga digunakan sebagai media siswa mengirim tugas ke guru. Hal ini merupakan sebuah terobosan yang sangat bermanfaat dalam proses pembelajaran.

Berdasarkan fakta penelitian diketahui bahwa penggunaan media pembelajaran berbasis ICT meliputi penggunaan what's app, blog, dan e-mail. Dalam implementasinya ketiga media tersebut dikolaborasikan dalam proses pembelajaran yang mana what's app berfungsi sebagai media siswa berdiskusi diluar jam pelajaran, blog berfungsi sebagai media siswa untuk mengakses materi pembelajaran yang kemudian materi dari blog tersebut dijadikan bahan diskusi siswa didalam grup chat what's app, dan e-mail berfungsi sebagai media siswa mengumpulkan tugas-tugas yang diberikan oleh guru Pendidikan Agama Islam. Kombinasi ke tiga media tersebuta merupakan bentuk dari pengembangan media pembelajaran berbasis ICT.

Penggunaan media what's app, blog, dan e-mail di madrasah ini merupakan media pembelajaran berbasis ICT yang baru dalam bentuk software. sebelum media what's app, blog, dan e-mail di implementasikan sebagai bentuk pengembangan media pembelajaran berbasis ICT, guru Pendidikan Agama Islam sebelumnya telah menggunakan media pembelajaran berbasis ICT yang telah disediakan oleh madrasah seperti LCD Projector sebagai bentuk hardware dari media pembelajaran berbasis ICT dan Power Point sebagai bentuk software dari media pembelajaran bebasis ICT. Akan tetapi, kedua media tersebut hanya bisa digunakan saat berada di madrasah saja, oleh 
karena itu guru Pendidikan Agama Islam kemudian mengembangkan media pembelajaran berbasis ICT yang bisa digunakan diluar madrasah atau saat siswa telah berada di rumah masing-masing. Maka, dipilihlah what's app, blog, dan e-mail sebagai bentuk dari pengembangan media pembelajaran berbasis ICT yang dapat di akses dimanapun dan kapanpun.

\section{Kreativitas Guru Pendidikan Agama Islam Dalam Mengembangkan Media Pembelajaran Berbasis ICT Pada Proses Pembelajaran Pendidikan Agama Islam Di MTsN 1 Konawe.}

Kreativitas adalah suatu potensi yang besar dan penting dalam meningkatkantaraf hidup dan kepercayaan diri terhadap kemampuan yang dimiliki manusia. Karena itu, kreativitas dapat dinilai sebagai suatu ide atau pola pikir seseorang yang timbul secara spontan dan imajinatif yang memberikan hasil penemuan baru, yakni kemampuan mendefinisikan kembali. Dari hasil berfikir tersebut terciptalah suatu motivasi untuk mewujudkan sebuah ide yang memiliki manfaat dalam proses pembelajaran.Dalam Q.S An-Nahl Ayat 17 Allah Subhanahu Wata'ala Berfirman:

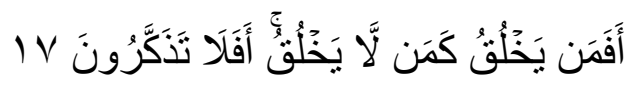

Terjemahannya: "Maka apakah (Allah) yang menciptakan itu sama dengan yang tidak dapat menciptakan (apa-apa)?. Maka mengapa kamu tidak mengambil pelajaran.”(Departemen Agama Republik Indonesia, 2002)

Seorang pendidik dikatakan memiliki jiwa kreatifitas dengan beberapa ciri diantaranya adalah adanya keinginan untuk mengubah hal-hal disekelilingnya menjadi lebih baik, memiliki kepekaan untuk bersikap terbuka serta tanggap terhadap segala sesuatu, siap mencoba dan melaksanakan, bersedia mencurahkan waktu dan tenaga untuk mencari serta mengembangkan, dan memiliki optimisme (Asfandiyar, 2010).

\section{a. Keinginan untuk mengubah hal-hal disekililingnya menjadi lebih baik}

Salah satu motivasi Guru Pendidikan Agama Islam dalam mengimplementasikan media pembelajaran berbasis ICT dikarenakan ingin merubah proses dan hasil pembelajaran menjadi lebih baik. Berdasarkan hasil penelitian diketahui bahwa tujuan diimplementasikannya media pembelajaran berbasis ICT tidak lain adalah untuk mengubah proses dan hasil pembelajaran menjadi lebih baik. Hal ini dapat dilihat dari kemampuannya dalam mengembangkan media pembelajaran berbasis ICT yaitu dengan mengkombinasikan beberapa aplikasi yakni What's App, Blog, dan E-Mail dalam 
kegiatan belajar mengajar. Sebagaimana diketahui Rahmat aziz dalam bukunya (Aziz, 2010) mengemukakan bahwa: "Kreativitas adalah interaksi antara sikap, proses, dan lingkungan dimana seseorang atau sekelompok orang menghasilkan suatu karya yang dinilai baru dan berguna dalam konteks sosialnya. Kreativitas merupakan aspek yang sangat penting dan berharga dalam setiap usaha manusia, sebab melalui kreativitas akan dapat ditemukan dan dihasilkan berbagai teori, pendekatan dan cara baru yang sangat bermanfaat bagi kehidupan".

Berdasarkan pendapat dari Rahmat Aziz di atas diketahu bahwa guru Pendidikan Agama Islam di MTsN 1 Konawe adalah seorang guru yang kreatif karena dapat menghasilkan sebuah inovasi dalam proses pembelajran yaitu menggunakan media pembelajaran berbasis ICT dengan cara mengkombinasikan What's App, Blog, dan Email. Konsep pengembangan media pembelajaran berbasis ICT yang di kemukakan oleh guru Pendidikan Agama Islam di MTsN 1 Konawe adalah konsep pengembangan dalam bentuk Innovation, dengan ide atau gagasan untuk mengkombinasikan tiga media, yaitu What's app, Blog, dan E-mail sebagai media pembelajaran.

\section{b. Kepekaan untuk bersikap terbuka dan tanggap terhadap terhadap sesuatu}

Guru Pendidikan Agama Islam di MTsN 1 Konawe merupakan seorang guru yang memiliki potensi kreatif dalam dirinya, sebab guru merupakan seorang yang peka terhadap situasi lingkungannya dan selalu terbuka terhadap apa yang ada disekitarnya. Hal ini dapat dilihat dari bentuk pengembangan media pembelajaran berbasis ICT yang ia lakukan, ini menandakan bahwa ia adalah seorang Guru yang sangat peduli dengan keadaan sekitarnya dalam hal ini adalah proses pembelajaran.

Hasil penelitian menunjukkan bahwa, alasan Guru Pendidikan Agama Islam di MTsN 1 Konawe berinisiatif untuk mengembangkan media pembelajaran berbasis ICT dengan menggunakan Whats app, Blog, dan E-Mail adalah karena melihat dampak negatif dari perkembangan teknologi yang semakin maju. Perkembangan teknologi yang semakin maju adalah sesuatu yang tidak bisa kita hindari sebab perkembangan teknologi ini akan sejalan dengan perkembangan ilmu pengetahuan. Muhammad Ngafifi dalam tulisannya (Ngafifi, 2014) mengatakan bahwa :

Kemajuan teknologi merupakan sesuatu yang tidak bisa kita hindari dalam di era modern ini, karena kemajuan teknologi akan berjalan sesuai dengan kemajuan ilmu pengetahuan. Teknologi yang sebenarnya merupakan alat bentu/ekstensi kemampuan diri manusia. Dewasa ini, telah menjadi sebuah kekuatan yang justru 
membelenggu perilaku dan gaya hidup kita sendiri. Dengan adanya bukti nyata tentang kelebihan teknologi yang begitu pesat baik dalam sosial maupun kehidupan manusia, menjadikah suatu kebutuhan pada setiap perbuaan yang dilakukan, sehingga inovasi tersebut perlu lebih ditingkatkan.

Olehnya itu, penggunaan teknologi jika tidak direduksi tentunya akan menghasilkan dampak negatif dari penggunaan teknologi itu sendiri. Sebagai upaya preventif yang dilakukan, guru Pendidikan Agama Islam di MTsN 1 Konawe mengembangkan media berbasis ICT ini sebagai media pembelajaran dengan harapan dapat mereduksi penggunaan teknologi secara positif. Pengembangan media pembelajaran berbasis ICT oleh guru Pendidikan Agama Islam di MTsN 1 Konawe ini menjadi suatu contoh bagi guru lain agar terdorong untuk berupaya melakukan pembaharauan dan mereduksi perkembangan teknologi secara positif khususnya dalam proses pembelajaran Pendidikan Agama Islam. Media yang digunakan oleh guru Pendidikan Agama Islam ini memberikan semangat dan motivasi terhadap guru lain untuk melakukan hal yang sama dengan apa yang dilakukannya.

\section{c. Siap Mencoba dan Melaksanakan}

Kemampuan untuk siap mencoba dan melaksanakan adalah suatu hal yang harus dimiliki oleh seorang guru. guru dituntut mampu menerima perubahan sebagai suatu ciri kehidupan, memahami berbagai akibatnya bagi organisasi pendidikan, mengidentifikasi perlunya perubahan, merencanakan, melaksanakan, serta mengevaluasi perubahan guru yang sesuai dengan kondisi globalisasi adalah guru yang mampu menguasai dan mengendalikan perubahan-perubahan yang berwawasan IPTEK. Mengakomodasi berbagai perubahan ilmu pengetahuan dan teknologi dijadikan bahan pemikiran bagi siswa dalam rangka pendidikan. Perubahan-perubahan yang terjadi dalam dunia pendidikan ini membuat guru Pendidikan Agama Islam di MTsN 1 Konawe mencoba dan melaksanakan pengembangan media pembelajaran berbasis ICT. Hal ini didasari karena di era globalisasi dengan perkembangan teknologi yang semakin majuguru dituntut untuk bisa menguasai teknlogi yang ada khususunya guru Pendidikan Agama Islam. Sebagaimana Kartilawati dan Mawaddatan Warahmah mengatakan (Kartilawati \& Warohmah, 2014):

Teknologi informasi yang berkembang dengan pesat menuntutseorang guru untuk memanfaatkannya dalam dunia pendidikan dalam lingkup luas dan untuk proses pembelajaran dalam lingkup kecil secarakolektif dan dengan keahlian yang 
memadai. Tentunya penggunaanteknologi informasi tersebut dapat dipahami secara jernih untukmencapai tujuan akhir dari tujuan pendidikan nasional.

Berdasarkan pandangan Kartilawati dan Mawaddatan Warahmah di atas dapat diketahui bahwa Perkembangan Teknologi Informasi dan Komunikasi yang semakin cepat dewasa ini secara langsung maupun tidak langsung memberikan pengaruh yang signifikan terhadap dunia pembelajaran, terutama kepada guru Pendidikan Agama Islam. Pengaruh yang signifikan ini tentunya akan membawa sebuah perubahan besar untuk guru itu sendiri. Oleh karena itu guru Pendidikan Agama Islam dituntut untuk bisa melaksanakan dan mencoba sesuatu yang bermanfaat dalam dunia pendidikan khususnya dalam proses pembelajaran untuk bisa beradaptasi dengan perubahan yang sedang terjadi.

Kemampuan untuk siap mencoba dan melaksanakan pada guru Pendidikan Agama Islam di MTsN 1 Konawe dapat dilihat dari keberaniannya untuk mencoba dan melaksanakan pengembangan media pembelajaran berbasis ICT dengan menggunakan what's app, blog, dan, e-mail dalam proses pembelajaran Pendidikan Agama Islam. Penggunaan what's app, blog, dan, e-mail dalam proses pembelajaran di MTsN 1 Konawe sendiri merupakan sesuatu yang baru akan tetapi itu tidak menjadi penghalang bagi guru Pendidikan Agama Islam untuk tetap mencoba dan menggunakan ketiga media tersebut dalam proses pembelajaran. Keberanian ini merupakan sesuatu yang patut menjadi contoh bagi guru lain untuk siap mencoba dan melaksanakan sesuatu yang bermanfaat dalam proses pembelajaran. Keberanian untuk mencoba dan melaksanakan sesuatu adalah modal utama dalam mewujudkan tujuan yang ingin dicapai.

\section{d. Bersedia Mencurahkan Waktu dan Tenaga untuk Mencari dan Mengembangkan}

Pada zaman ini orang yang berkuasa adalah orang yang menguasai teknologi dan informasi. Untuk dapat bersaing dalam era teknologi dan informasi yang mengandalkan kecerdasan dan fleksibilitas ini diperlukan kemampuan berpikir kreatif. Guru Pendidikan Agama Islam di MTsN 1 Konawe merupakan seorang guru yang bersedia mencurahkan waktu dan tenaganya untuk mencari dan mengembangkan. Hal ini dibuktikan dari pengembangan media pembelajaran berbasis ICT yang dilakukan dengan menggunakan what's app, blog, dan e-mail. 
Berdasarkan hasil penelitian diketahui bahwa proses membuat sesuatu yang baru membutuhkan waktu dan tenaga untuk menarik perhatian siswa. Oleh karena itu dibutuhkan kemampuan berfikir kreatif yang mumpuni. Dalam berfikir kreatif ada beberapa tahapan yang dibutuhkan. Sebagaimana Bimo Walgito mengemukakan dalam bukunya (Walgito, 2004) sebagai berikut: 1) Persiapan (preparation), yaitu tahapan seseorang memformulasikan masalah, dan mengumpulkan fakta-fakta atau materi yang dipandang berguna dalam memperoleh pemecahan yang baru. Ada kemungkinan apa yang difikirkan itu tidak segera memperoleh pemecahannya, tetapi soal itu tidak hilang begitu saja. Tetapi masih terus berlangsung dalam diri individu yang bersangkutan, 2) Inkubasi, yaitu berlangsungnya masalah tersebut dalam jiwa seseorang karena tidak segera memperoleh pemecahan masalah, 3) Pemecahan atau iluminasi, yaitu tahapan seseorang telah mendapatkan gagasan/inspirasi pemecahan masalah, 4) Evaluasi, yaitu tahapan mengecek apakah pemecahan yang diperoleh tepat atau tidak berdasarkan realitas, dan 5) Revisi, yaitu tahapan memperbaiki atau mengubah keputusan yang telah diambil sesuai dengan realitas yang terjadi.

Guru sebagai seorang kreator dan motivator yang berada di pusat proses pendidikan senantiasa berusaha untuk menemukan cara yang lebih baik dalam melayani peserta didik. Kreativitas menunjukkan bahwa yang dikerjakan oleh guru tidak semata sesuatu yang rutin saja. Dengan demikian tahapan-tahapan kreativitas guru ini akan tercermin pada tahapan proses pembelajaran. Seorang guru yang berfikir kreatif tidak akan pernah merasa terhambat dengan rintangan yang dihadapinya dan akan selalu ikhlas dalam melaksanakannya. Segala rintangan akan selalu dihadapinya dengan senyuman dan hati yang lapang. Hal ini merupakan sebuah bentuk etos kerja seorang guru, sebagaimana dalam Q.S AT-Taubah Ayat 105 Allah Subhanahu Wata'ala ber firman :

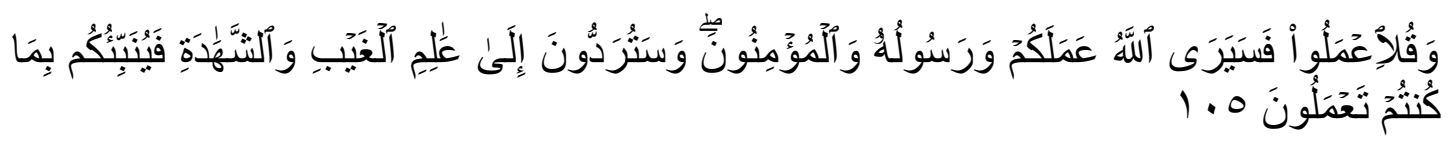

Terjemahannya: "Dan Katakanlah: "Bekerjalah kamu, maka Allah dan Rasul-Nya serta orang-orang mukmin akan melihat pekerjaanmu itu, dan kamu akan dikembalikan kepada (Allah) Yang Mengetahui akan yang ghaib dan yang nyata, lalu diberitakan-Nya kepada kamu apa yang telah kamu kerjakan” (Departemen Agama Republik Indonesia, 2002). 
Firman Allah Subhanahu Wata'ala di atas merupakan sebuah motivasi untuk orang-orang mukmin untuk beramal dan bekerja. Melalui ayat ini, Allah Subhanahu wa Ta'ala memerintahkan hamba-Nya untuk beramal, bekerja, berusaha, dan banyak berbuat. Allah Subhanahu Wata'ala melihat amal dan pekerjaan hamba-Nya. Demikian pula Rasulullah semasa hidupnya, beliau melihat amal itu. begitupun dengan orangorang yang beriman. Sehingga motivasinya, beramallah dan bekerjalah. Dengan ikhlas dan sungguh-sungguh. Jangan riya', jangan mengharap pujian manusia karena Allah-lah yang melihat dan menilai amal-amal itu. Kemudian Rasulullah dan orang-orang beriman juga akan mengetahui dengan sendirinya, tanpa dipamer-pamerkan dan tanpa didemonstrasikan. Inilah etos kerja seorang muslim khususnya seorang guru yang memiliki tugas mulia untuk mengajar dan membimbing siswa. Ayat ini memotivasi kepada guru untuk terus bekerja dengan ikhlas dan sungguh-sungguh. Proses itulah yang dilihat dan dinilai Allah,bukan hasilnya. Allah tidak menilai kita berdasarkan hasil, tetapi berdasarkan proses.

Guru Pendidikan Agama Islam di MTsN 1 Konawe merupakan guru yang senantiasa berfikir kreatif dan memiliki etos kerja yang tinggi dalam mengemban tugas yang mulia sebab dalam prosesnya guru Pendidikan Agama Islam di MTsN 1 Konawe bersedia meluangkan waktu dan tenaganya untuk mencari sesuatu yang menarik untuk siswa dan mengembangkan media pembelajaran berbasis ICT agar tujuan pembelajaran yang diharapkannya dapat tercapai.

\section{e. Memiliki Optimisme}

Optimis secara umum berarti selalu percaya diri dan berpandangan atau berpengharapan baik dalam segala hal. Dalam Islam sering disebut dengan Raja' yaitu selalu mengaitkan hati terhadap sesuatu yang disukai pada masayang akan datang (ta'liq al-qalbi bi mahbub fi mustaqbal) dan harus dilaluioleh usaha yang sungguh-sungguh (Ilyas, 2007). Setiap detik waktu perjalanan kehidupan mengajarkan kepada setiap orang untukbersikap optimis, Sikap positif tidak muncul begitu saja, melainkan harus ditumbuhkan dan dilatih. Ketika seorang guru mengajarkan setiap murid untuk optimis, patutlah guru tersebut bertanya pada diri sendiri apakah ia optimis atau pesimis?. tidak ada kata terlambat untuk menjadi orang yang optimis. 
Hal ini merupakan sebuah sikap percaya diri yang dimiliki oleh Guru Pendidikan Agama Islam di MTsN 1 Konawe. Sebagaimana dalam Q.S Az-Zumar Ayat 53 Allah Subhanahu Wata'ala berfirman :

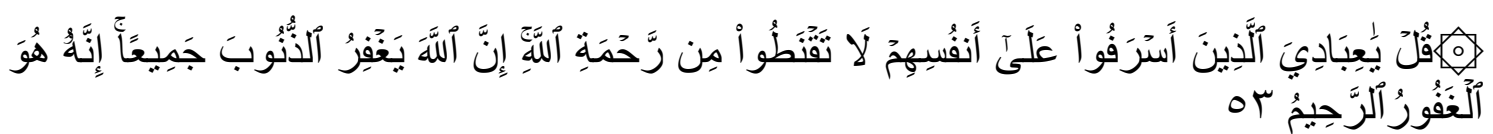

Terjemahannya: "Katakanlah: "Hai hamba-hamba-Ku yang malampaui batas terhadap diri mereka sendiri, janganlah kamu berputus asa dari rahmat Allah. Sesungguhnya Allah mengampuni dosa-dosa semuanya. Sesungguhnya Dialah Yang Maha Pengampun lagi Maha Penyayang." (Departemen Agama Republik Indonesia, 2002)

Dalam Ayat di atas Allah Suhanahu Wata'ala menyerukan untuk tidak berputus asa dari rahmat Allah Subhanahu Wata'ala. Berputus asa dari rahmat Allah Subhanahu Wata'ala. termasuk sikap tercela. Seorang mukmin harus selalu optimis akan mendapat rahmat Allah Subhanahu Wata'ala. Rahmat Allah Subhanahu Wata'ala akan diberikan kepada mereka yang bersungguh-sungguh mendekatkan diri kepada-Nya. Setan akan selalu menggoda orang beriman supaya terjerumus ke dalam dosa. Setelah terjerumus ke dalam dosa, setan akan menanamkan sifat putus asa dalam diri manusia. Al-Qur'an telah menegaskan bahwan setiap muslim dilarang untuk berputus asa, karen sifat putus asa merupakan karakter orang kafir. Sebagaimana dalam Q.S Yusuf Ayat 87 Allah Subhanahu Wata'alaberfirman :

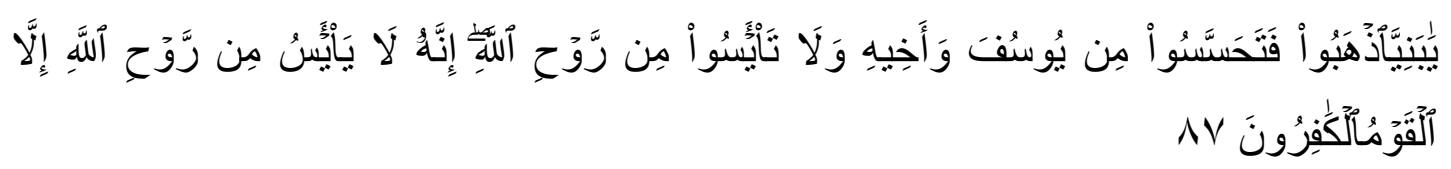

Terjemahannya: "Hai anak-anakku, pergilah kamu, maka carilah berita tentang Yusuf dan saudaranya dan jangan kamu berputus asa dari rahmat Allah. Sesungguhnya tiada berputus asa dari rahmat Allah, melainkan kaum yang kafir" (Departemen Agama Republik Indonesia, 2002)

Berdasarkan ayat di atas peneliti menyimpulkan bahwa berputus asa merupakan sesuatu yang dilarang oleh Allah Subhanahu Wata'ala. Oleh karena itu seorang muslim sebisa mungkin menghindari perilaku berputus asa tersebut dan harus selalu percaya diri dalam menjalankan sesuatu yang bermanfaat. Sifat optimis dapat memberikan motivasi positif bagi kehidupan manusia. Jika manusia mampu menempatkan dirinya sebagai orang yang positif, maka manusia juga akan mampu mengembangkan seluruh potensinya. Hal ini sebagaimana yang dilakukan oleh guru Pendidikan Agama Islam dengan optimisme yang dimilikinya maka teraktualisasilah potensi yang dimilikinya 
melalui kreativitas yang memberikan kontribusi positif dalam melahirkan inovasi pembelajaran. Dengan perilaku dan cara pandang positif, guru Pendidikan Agama Islam dapatt menjalin hubungan yang lebih baik dengan sesamanya dan lingkungan.

Berdasarkan hasil penelitian diketahui bahwa kreativitas guru Pendidikan Agama Islam di MTsN 1 Konawe dapat dilihat dari keinginan untuk mengubah hal-hal disekelilingnya menjadi lebih baik, memiliki kepekaan untuk bersikap terbuka serta tanggap terhadap segala sesuatu, siap mencoba dan melaksanakan, bersedia mencurahkan waktu dan tenaga untuk mencari serta mengembangkan, dan memiliki optimism.

Bentuk pengembangan media pembelajaran yang dilakukan oleh guru PAI di MTsN 1 Konawe merupakan suat hal yang memberikan dampak positif terhadap proses pembelajaran serta sehingga proses pembelajaran lebih efektif dan efisien. Heri Gunawan dalam bukunya (Gunawan, 2013) mengemukakan bahwa "Dengan adanya kreativitas guru dalam memanfaatkan media pembelajaran PAI maka setidaknya tujuan pemanfaatan media dapat berjalan. Setidaknya, secara umum manfaat media pembelajaran adalah memperlancar interaksi antara guru dengan siswa sehingga kegiatan pembelajaran lebih efektif dan efisien."

Secara khusus kreativitas guru PAI dalam mengembangkan media dalam pembelajaran dapat memberikan beragam manfaat diantaranya adalah proses pembelajaran menjadi lebih jelas, menarik, dan interaktif, efisiensi dalam waktu dan tenaga, meningkatkan kualitas hasil belajar siswa, menjadikan proses belajar dapat dilakukan dimana saja dan kapan saja, menumbuhkan sikap positif siswa terhadap materi dan proses belajar, serta mengubah peran guru ke arah yang lebih kreatif, positif dan produktif.

\section{Penutup}

Kreativitas adalah suatu potensi yang besar dan penting dalam meningkatkan taraf hidup dan kepercayaan diri terhadap kemampuan yang dimiliki manusia. Karena itu, kreativitas dapat dinilai sebagai suatu ide atau pola pikir seseorangyang timbul secara spontan dan imajinatif yang memberikan hasil penemuan baru, yakni kemampuan mendefinisikan kembali. Dari hasil berfikir tersebut tercipta suatu motivasi untuk mewujudkan sebuah ide yang memiliki manfaat dalam proses pembelajaran. 
Kreativitas guru Pendidikan Agama Islam di MTsN 1 Konawe dapat dilihat dari kemampuan dalam mengembangkan media pembelajaran berbasis ICT dalam proses pembelajaran. hal ini menunjukkan bahwa guru Pendidikan Agama Islam di MTsN 1 Konawe memiliki Keinginan untuk mengubah hal-hal disekitarnya menjadi lebih baik, Memiliki kepekaan untuk bersikap terbuka serta tanggap terhadap segala sesuatu, Berani mencoba dan melaksanakan, Mampu mencurahkan waktu dan tenaga untuk mencari serta mengembangkan, dan Memiliki optimisme. Secara umum guru Pendidikan Agama Islam di MTsN 1 Konawe adalah guru yang kreatif sebab dapat berinovasi mengembangkan media pembelajaran berbasis ICT dengan mengkolaborasikan whats app, blog, dan e-mail dalam proses pembelajaran. akan tetapi, peneliti merekomendasikan agar kedepannya guru Pendidikan Agama Islam di MTsN 1 Konawe dapat lebih mengupgrade media pembelajaran berbasis ICT dengan menggunakan aplikasi yang lebih efektif lagi dalam proses pembelajaran. karena menurut peneliti media pembelajaran berbasis ICT yang digunakan oleh guru Pendidikan Agama Islam masih terdapat celah yang menjadikan media tersebut kurang efektif. Akan tetapi pengembangan media pembelajaran ICT yang dipergunakan oleh guru Pendidikan Agama Islam di MTsN 1 Konawe patut diapresiasi sebesar-besarnya karena guru Pendidikan Agama Islam di MTsN 1 Konawe mampu melakukan sebuah inovasi yang belum tentu bisa dilakukan oleh guru lain serta dapat memberikan motivasi kepada guru lain untuk dapat menjadi lebih kreatif lagi dalam mengembangkan media pembelajaran dengan memanfaatkan perkembangan teknologi.

\section{DAFTAR PUSTAKA}

Alsaleem, B. I. A. (2013). The Effect Of" Whatsapp" Electronic Dialogue Journaling On Improving Writing Vocabulary Word Choice And Voice Of EFL Undergraduate Saudi Students. Arab World English Journal, 4(3), 213-225.

Asfandiyar, A. Y. (2010). Kenapa Guru Harus Kreatif. Jakarta: Mizan Media Utama. Asnawir, B. U., \& Usman, M. B. (2002). Media pembelajaran. Jakarta: Ciputat Pers.

Aziz, R. (2010). Psikologi Pendidikan: Model Pengembangan Kreativitas dalam Praktik Pembelajaran. Malang: UIN-Maliki Press.

Darmadi, H. (2000). Kemampuan Dasar Mengajar. Alfabeta: Bandung.

Dearstyne, B. W. (2011). Smart phones: The new information revolution?. The Information Management Journal, 39. 
Departemen Agama Republik Indonesia. (2002). Al-Qur'an dan Terjemahannya. Surabaya: CV Darus Sunnah.

Falahudin, I. (2014). Pemanfaatan Media dalam Pembelajaran. Jurnal Lingkar Widyaiswara, 1(4), 104-117.

Gunawan, H. (2013). Kurikulum dan Pembelajaran Pendidikan Agama Islam. Bandung: Alfabeta.

Ilyas, Y. (2007). Kuliah Akhlak. Yogyakarta: LPPI Universitas Muhamadiyah.

Kartilawati, K., \& Warohmah, M. (2014). Profesionalisme Guru Pendidikan Agama Islam di Era Teknologi Informasi dan Komunikasi. Ta'dib: Jurnal Pendidikan Islam, 19(01), 143-168.

Mawarsih, A. (2014). Pengaruh Electronic Mail Sebagai Media Komunikasi Terkadap Mengerjakan Tugas Kuliah Mahasiswa. Ilmu Komunikasi, 337-338.

Muflih, M., Hamzah, H., \& Purniawan, W. A. (2017). Penggunaan smartphone dan interaksi sosial pada remaja di SMA Negeri I Kalasan Sleman Yogyakarta. Idea Nursing Journal, 8(1), 12-18.

Mujakir, M. (2017). Kreativitas Guru dalam Pembelajaran IPA Di Sekolah Dasar. Lantanida Journal, 3(1), 82-92.

Nasrullah, R. (2008). Handbook for Muslim Blogger. Jawa Timur: Mashun.

Ngafifi, M. (2014). Kemajuan Teknologi dan Pola Hidup Manusia dalam Perspektif Sosial Budaya. Jurnal Pembangunan Pendidikan: Fondasi Dan Aplikasi, 2(1).

Riyanti, B. P. D. (2003). Kewirausahaan Dari Sudut Pandang Psikologi Kepribadian. Jakarta: Grasindo.

Sanjaya, W. (2008). Kurikulum dan Pembelajaran (Teori \& Praktek KTSP). Jakarta: Kencana.

Walgito, B. (2004). Pengantar Psikologi Umum. Yogyakarta: Andi Offset. 